\author{
KRZYSZTOF ZAGROBELNY \\ ORCID: 0000-000304544-0088 \\ Uniwersytet Wrocławski \\ Instytut Prawa Cywilnego \\ Zakład Prawa Cywilnego i Prawa Międzynarodowego Prywatnego
}

\title{
RACJONALNY PRAWODAWCA - RATUNEK DLA SOLIDARNEJ ODPOWIEDZIALNOŚCI INWESTORA ZA ZAPŁATE WYNAGRODZENIA PODWYKONAWCY
}

\begin{abstract}
Abstrakt: Remedium na problemy płatnicze podwykonawców, którzy nie otrzymywali wynagrodzenia za wykonane przez siebie roboty budowlane, miało być wprowadzenie do kodeksu cywilnego solidarnej odpowiedzialności inwestora. Wyrażając zgodę na zawarcie umowy podwykonawczej, miał on odpowiadać solidarnie z wykonawcą za zapłatę wynagrodzenia podwykonawcy. Sposób, w jaki został zredagowany przepis art. $647^{1}$ k.c., nie pozwalał osiągnąc celów założonych przez prawodawcę, dlatego konieczne stało się odwołanie do paradygmatu racjonalnego prawodawcy. Tylko dzięki temu zabiegowi przepis ten uzyskał akceptowalną, niesprzeczną wewnętrznie treść.
\end{abstract}

Słowa kluczowe: umowa o roboty budowlane, inwestor, wykonawca, podwykonawca, solidarna odpowiedzialność inwestora, racjonalny prawodawca

1. Bywają normy prawne, których treść da się ustalić stosunkowo łatwo, bez potrzeby stosowania skomplikowanych zabiegów interpretacyjnych, ale chyba nie ma takich, które - wbrew paremii clara non sunt interpretanda - wcale nie wymagają wykładni ${ }^{1}$. Z pewnością znaczna liczba przepisów wymaga uważnej analizy wykorzystującej cały arsenał metod i środków pozwalających ustalić ich ostateczną treść. Jest przy tym zrozumiałe, że wykładnia przepisów należących do różnych gałęzi obowiązującego prawa, dyscyplin dogmatycznych, korzysta z dorobku prawoznawstwa - sięga do badań prowadzonych przez teoretyków prawa. W doktrynie prawa cywilnego próba ustalenia treści przepisu nie kończy się przecież na stosowaniu wykładni językowej wspartej paralingwistycznymi środkami wyrazu oraz wykładni systemowej. Stosunkowo często korzysta się również między inny-

${ }^{1}$ Zob. Z. Radwański, A. Olejniczak, Prawo cywilne - część ogólna, Warszawa 2017, s. 67. 
mi z pojęcia racjonalnego ustawodawcy ${ }^{2}$, zazwyczaj nie posługując się wprost tym określeniem. Pozostawiając szczegółowe wyjaśnienie tej konstrukcji nauce zajmującej się teorią prawa, warto jednak zauważyć, że pewne jej elementy wymagają rozważenia także w procesie wykładni przepisów prawa cywilnego. Określenie, kto kryje się za racjonalnym ustawodawcą, a zatem, czy ujmować go na przykład w kategorii socjologicznej, a także czy na przykład wyłożone w toku procesu legislacyjnego motywy prowadzące do powstania normy o określonej treści należy brać pod uwagę w ramach wykładni wykorzystującej motyw racjonalnego ustawodawcy, są niezmiernie istotne dla ostatecznego wyniku prowadzonego rozumowania. Wydaje się, że zdrowy rozsądek przemawiać będzie za tym, że nie zawsze rzeczywiste i możliwe do odtworzenia motywacje stanowić będą ramy prowadzonego rozumowania odtwarzającego wypowiedź ustawową, co wiąże się z traktowaniem założenia o mądrym, racjonalnym i sprawiedliwym stanowieniu prawa jako idei niekoniecznie znajdującej odbicie w rzeczywistości, a zatem kontrfaktycznej ${ }^{3}$. Wyjściem z takiej sytuacji jest założenie, że idea racjonalnego ustawodawcy ma charakter idealistyczny i jest wzorem w stanowieniu prawa ${ }^{4}$, co niekoniecznie w przypadku wykładni konkretnych przepisów jest motywem użytecznym, albo da się przyjmować, że odwołanie się do woli rzeczywistego prawodawcy należy traktować jako jeden $\mathrm{z}$ wielu argumentów interpretacyjnych, a nie jako wyłączną podstawę konstruowania ogólnej normatywnej teorii wykładni prawa ${ }^{5}$. Przyjęcie takiego założenia z kolei prowadzić będzie do wniosku, że nie ma bezpośredniej sprzeczności między teorią racjonalnego prawodawcy a argumentem odwołującym się do woli rzeczywistego prawodawcy, ponieważ ta nie stanowi sama w sobie alternatywnej, całościowej wykładni ${ }^{6}$. Nie bez racji podnosi się, że racjonalność prawodawcy jest założeniem modelowym i to w dodatku apriorycznym ${ }^{7}$.

2. W doktrynie prawa cywilnego wyraźnie zakłada się, że w procesie wykładni przepisów należących do tej gałęzi prawa, prócz sięgania do dyrektyw systemowych, aby uniknąć norm wzajemnie niezgodnych, konieczne może okazać się odwołanie do preferowanych przez dany system celów i wartości ${ }^{8}$. A to, jak wynika z poczynionych uwag, jest właśnie nawiązaniem do konstrukcji racjonalnego prawodawcy. Wyraźnie należy przy tym zaznaczyć, że w dyscyplinach dogmatycznych, poszukiwanie treści określonej normy z wykorzystaniem pa-

2 Ibidem, s. 69. Koncepcja racjonalnego ustawodawcy wiąże się z osobą L. Nowaka, zwłaszcza z pracą Interpretacja prawnicza. Studium z metodologii prawoznawstwa, Warszawa 1973.

${ }^{3}$ P. Kantor-Kozdrowicki, Racjonalność prawodawcy jako paradygmat nauk prawnych, „Folia Iuridica Universitatis Wratislaviensis" 7, 2018, s. 99.

${ }^{4}$ Ibidem, s. 103.

5 A. Borowicz, Argument interpretacyjny odwolujacy się do woli rzeczywistego prawodawcy „Studia Prawno-Ekonomiczne” 79, 2009, s. 24.

6 Ibidem.

7 D. Szenkowski, Pluralizm wartości a wola i racjonalność ustawodawcy - konflikt aksjologiczny w systemie i stosowaniu prawa, „Dialogi Polityczne” 2010, nr 13, s. 184.

8 Z. Radwański, A. Olejniczak, op. cit., s. 69-71. 
radygmatu racjonalnego prawodawcy ściśle łączy się z koniecznością ustalenia punktu odniesienia, czyli z określeniem źródła wspomnianych wartości. Wskazuje się, że mają być one wywodzone z wartości konstytucyjnych, co uznać należy za oczywiste, ale chyba także ich źródłem mogą być panujące w społeczeństwie przekonania i postawy ${ }^{9}$. W ramach norm prawa cywilnego regulujących relacje prawne w zdecydowanej większości oparte o autonomię woli podmiotów to ostatnie zastrzeżenie wydaje się mieć niemałe znaczenie. Warto też zwrócić uwagę, że w praktyce stosowania prawa koncepcja racjonalnego prawodawcy raczej nie występuje $\mathrm{w}$ tej postaci, która precyzyjnie określa chronione wartości, ale w jej uproszczonej formie wskazującej przede wszystkim cele aktu normatywnego, co określa się mianem wykładni celowościowej ${ }^{10}$. Tym sposobem da się usunąć wątpliwości powstające w procesie wykładni określonych przepisów, gdy inne jej metody nie dają satysfakcjonujących wyników.

3. Przekonanie o użyteczności tytułowej konstrukcji odwołującej się do elementów funkcjonalnych można przetestować na podstawie studium przypadku regulacji solidarnej odpowiedzialności inwestora za zapłatę wynagrodzenia należnego podwykonawcy. Wspomniana instytucja została wprowadzona do kodeksu cywilnego ustawą z dnia 14 lutego 2003 roku o zmianie ustawy — kodeks cywilny oraz niektórych innych ustaw ${ }^{11}$. Dodany art. $647^{1}$ k.c. składał się z sześciu jednostek redakcyjnych dotyczących różnych zagadnień, a jego podstawowym celem było nałożenie na inwestora (w niektórych okolicznościach także na wykonawcę) solidarnego obowiązku zapłaty podwykonawcy wynagrodzenia za wykonane roboty budowlane - takie, które wykonał zgodnie z umową zawartą z wykonawcą. Co ciekawe, przepis ten, będący wynikiem inicjatywy rządu, przebył całą ścieżkę legislacyjną; można by rzec, w normalnym trybie ${ }^{12}, \mathrm{w}$ trakcie którego dałoby się ukształtować jego brzmienie w sposób zapewniający realizację założonych celów. Zostały one w miarę szczegółowo wyłożone w niezbyt obszernym druku sejmowym nr 888 przedstawionym marszałkowi sejmu pismem z dnia 16 września 2002 roku. Wywodzono w nim, że na rynku świadczeń budowlanych coraz częściej podwykonawcom, zazwyczaj małym i średnim przedsiębiorcom, nie reguluje się należności za wykonane przez nie świadczenia dotyczące robót budowlanych. Dłużnicy takich zobowiązań dysponują często jedynie pozornym potencjałem, co sprawia, że egzekwowanie długów nie jest skuteczne. Stąd, jak wyjaśniono, wzięła się propozycja, aby inwestor i wykonawca (generalny wykonawca), a także dalszy podwykonawca zawierający umowę z kolejnym podwykonawcą, odpowia-

9 P. Machnikowski, [w:] Zarys prawa cywilnego, red. E. Gniewek, P. Machnikowski, Warszawa 2018, s. 121.

10 Ibidem.

11 Dz.U. Nr 49, poz. 408

12 Co wobec obecnych praktyk stosowanych przy uchwalaniu ustaw (niecały dzień zajęło parlamentowi VIII kadencji procedowanie i uchwalenie siódmej zmiany w ustawie o Sądzie Najwyższym) nie jest okolicznością bez znaczenia. 
dali solidarnie za zobowiązania powstałe w związku z realizacją przez nich robót budowlanych na zlecenie inwestora. Podniesiono, że odpowiedzialność solidarna dłużników (art. 366 k.c.) jest najdalej idącą odpowiedzialnością za powstałe zobowiązanie $\mathrm{i}$ to niezależnie od czyjejkolwiek winy, ale jak zauważono - stwarzającą przy tym ryzyko ponownej zapłaty za wcześniej już zapłacone roboty budowlane. Mimo to założono, że proponowane rozwiązanie będzie miało wpływ na zachowanie inwestora, zmuszając go do wnikliwej oceny kondycji finansowej i zdolności kredytowej wykonawcy, a w razie wątpliwości da mu sposobność żądania odpowiednich dodatkowych zabezpieczeń. Dalszym, wyraźnie wskazanym skutkiem proponowanych rozwiązań miało być to, że umowy podwykonawcze będą zawierane pod warunkiem akceptacji ich przez inwestora, podwykonawca zaś będzie miał tę sposobność jedynie za zgodą wykonawcy i inwestora. Zwrócono przy tym uwagę, że potencjalne wątpliwości co do praw i obowiązków ich stron wyeliminują zawarte w nich postanowienia, w myśl których zmiany umów, uzupełnienia i aneksy powinny zachować formę pisemną ad solemnitatem. W celu skutecznej ochrony interesów inwestora i wykonawcy robót budowlanych nowym przepisom zdecydowano się nadać charakter bezwzględnie obowiązujący (ius cogens). W ocenie skutków regulacji zwrócono jeszcze uwagę na to, że wejście w życie projektowanego przepisu, mimo że cywilnoprawnego, będzie mieć znaczenie dyscyplinujące, nie naruszając przy tym porządku prawnego. Należy też nadmienić, że w powołanym dokumencie ujawniającym zamiary rzeczywistego prawodawcy szczegółowa konstrukcja proponowanego przepisu nie była szerzej analizowana. Uzasadnienie nowelizacji kodeksu cywilnego zawarte w druku sejmowym nr 888 wyraźnie wskazuje, że przez dodanie art. $647^{1}$ zmierzano do osiągnięcia następujących celów: wprowadzenia solidarnej odpowiedzialności inwestora i ewentualnie wykonawcy lub dalszego podwykonawcy za zapłatę wynagrodzenia należnego temu, kto wykonał roboty budowlane; wprowadzenia reguły, w myśl której zawarcie umów z podwykonawcami następuje pod warunkiem ich akceptacji przez inwestora; poddania zawieranych umów wymaganiom formalnym pod rygorem nieważności.

4. Nie trzeba przywoływać koncepcji racjonalnego prawodawcy aby wykazać, że pierwszy z wymienionych celów został osiągnięty. Bez względu na to, w jaki sposób ostatecznie należało wykładać art. $647^{1}$ k.c. — w wersji wprowadzonej ustawą z dnia 14 lutego 2003 roku czy też w wersji obecnie obowiązującej $^{13}$ - z całą pewnością w zobowiązaniu $\mathrm{z}$ umowy o roboty budowlane pojawiła się nowa instytucja, w ramach której dłużnikiem odpowiadającym za cudzy dług stawał się inwestor (także wykonawca) niezawierający umowy z podwykonawcą (dalszym podwykonawcą). Jest przy tym oczywiste, że ta szczególna sytuacja jest wyjątkiem od obowiązującej w prawie cywilnym zasady związania zobo-

13 Zmiana treści art. $647^{1}$ k.c. dokonana została ustawą z dnia 7 kwietnia 2017 roku o zmianie niektórych ustaw w celu ułatwienia dochodzenia wierzytelności, Dz.U. poz. 933. 
wiązaniem jej stron, nie zaś osób trzecich. Przełamanie w tym wypadku jednej z ważniejszych reguł prawa obligacyjnego winno stanowić sygnał, aby nad wyraz starannie zaprojektować i określić przesłanki, kiedy tego typu przypadek może się zdarzyć. Osiągnięcie tak zakreślonego celu miał umożliwić $\S 2$ dodanego przepisu, według którego do zawarcia przez wykonawcę umowy o roboty budowlane z podwykonawcą jest wymagana zgoda inwestora (a do zawarcia kolejnych umów podwykonawczych konieczna była zgoda inwestora i wykonawcy). Powstanie zatem solidarnej odpowiedzialności inwestora odpowiadającego wraz z wykonawcą ${ }^{14}$ za zapłatę wynagrodzenia za roboty budowlane wykonane przez podwykonawcę uzależniono, co trzeba podkreślić, od zgody inwestora na zawarcie umowy podwykonawczej (czyli umowy między wykonawcą i podwykonawcą). Konsekwentnie założono, że zawarcie przez podwykonawcę umowy z dalszym podwykonawcą wymaga tym razem nie tylko zgody inwestora, ale również zgody wykonawcy (zob. $§ 3$ art. $647^{1}$ k.c.). Już samo przywołanie przepisów o zgodzie inwestora (wykonawcy) wskazuje, jak kluczowe znaczenie dla konstrukcji solidarnej odpowiedzialności za zapłatę wynagrodzenia należnego podwykonawcom ma określenie jej charakteru i treści.

5. Warto zaczać od tego, że wykładnia literalna art. $647^{1} \S 2$ k.c. niewiele tu wniesie, ponieważ w samym stwierdzeniu o konieczności zgody inwestora na zawarcie umowy przez wykonawcę z podwykonawcą nie mieści się wyjaśnienie, jakie skutki niesie dla nich jej zawarcie przed uzyskaniem zgody albo gdy ostatecznie jej nie udzielono. W szczególności, jaki jest wówczas status umowy podwykonawczej, a także, co jest z tym ściśle związane, jak kształtują się wzajemne uprawnienia i obowiązki jej stron wobec siebie. Najbardziej nawet wnikliwa analiza skupiona na treści powołanego przepisu nie udzieli odpowiedzi na postawione pytania. Dlatego też trzeba skorzystać z kolejnej metody, tym razem odwołującej się do systematyki kodeksu cywilnego. Zwraca ona uwagę na możliwość wykorzystania w tym wypadku przepisu art. 63 k.c. — zgodnie z jego treścią, jeżeli do dokonania czynności prawnej potrzebna jest zgoda osoby trzeciej, osoba ta może ją wyrazić także przed lub po złożeniu oświadczeń woli przez osoby dokonujące tej czynności, przy czym, co istotne, zgoda udzielona ex post ma charakter retroaktywny. W doktrynie prawa cywilnego nie kwestionuje się istnienia czynności, która - wymagając akceptacji osoby trzeciej — została bez niej dokonana. Taka czynność prawna, często nazywana „kulejącą” (negotium claudicans), nie jest obojętna dla jej stron. Przyjmuje się powszechnie, że w stanie zawieszenia trwającym do czasu, aż rozstrzygnie się kwestia wyrażenia lub niewyrażenia zgody, jej skutki prawne nie występują (są wstrzymane), a istniejąca wówczas bezskuteczność zawieszona wyklucza ustalenie nieważności czynności

14 Dla czytelności wywodu pomijane będą sytuacje, w których łańcuch podwykonawców jest dłuższy, o czym wspomina $\S 3$ art. $647^{1}$ k.c. 
dokonanej bez wymaganej zgody ${ }^{15}$. Mimo że osoba trzecia nie jest stroną dokonywanej czynności, to ostatecznie brak jej zgody powoduje, że taka czynność jest nieważna. Sankcja bezskuteczności zawieszonej zastąpiona zostaje dalej idącą nieważnością. Konfrontując ustalenia dotyczące konstrukcji zgody osoby trzeciej $\mathrm{z}$ art. 63 k.c. nie tylko z treścią art. $647^{1} \S 2$ k.c., ale dodatkowo z wyraźnie artykułowanym celem wprowadzenia nowelizacji (druk sejmowy nr 888: „Równocześnie przyjęto, że zawarcie umów z podwykonawcami przez wykonawcę nastąpi pod warunkiem akceptacji ich przez inwestora"), dość oczywiste było skojarzenie o zgodzie inwestora na zawarcie przez wykonawcę umowy o roboty budowlane z podwykonawcą jako czynności warunkującej pełną skuteczność takiej umowy. W doktrynie prawa cywilnego krótko po wprowadzeniu nowego przepisu przyjęto zatem, że mamy tu do czynienia z konstrukcją zgody osoby trzeciej na dokonanie czynności prawnej ${ }^{16}$. Wyraźnie podkreślano, że do chwili wyrażenia zgody przez inwestora umowa zawarta przez generalnego wykonawcę z podwykonawcą nie wywołuje skutków prawnych ${ }^{17}$. Prima facie w ocenie przedstawionego rozumowania trudno dostrzec wadliwość lub niekonsekwencję. Wykładnia literalna i systemowa wsparta dodatkowo jasno wyłożonymi motywami, jakimi kierował się rzeczywisty prawodawca, prowadzi właśnie do wniosku, że to decyzja inwestora ostatecznie decyduje o tym, czy umowa podwykonawcza będzie obowiązywać jej strony, czy też nie. Logiczne było więc założenie, że do czasu wyrażenia zgody inwestora umowa o roboty budowlane zawarte przez wykonawcę i podwykonawcę ma mieć status czynności „kulejącej” (negotium claudicans), czyli takiej, której skutki są zawieszone, w razie zaś ostatecznej odmowy udzielenia zgody staje się ona nieważna.

6. Jak widać, nie od razu zwrócono uwagę na istotne mankamenty takiego sposobu wykładania art. $647^{1}$ k.c. Mimo wyraźnych deklaracji zawartych w uzasadnieniu nowelizacji musiało $\mathrm{w}$ końcu pojawić się pytanie o rzeczywisty sens zgody inwestora na zawarcie umowy podwykonawczej - czy w przypadku powołanego przepisu chodziło o to, aby zmienić w całości wywodzący się z art. 356

15 Zob. P. Machnikowski, [w:] Kodeks cywilny. Komentarz, red. E. Gniewek, P. Machnikowski, Warszawa 2019, s. 150.

16 Zob. P. Drapała, Umowa o roboty budowlane, PPH 2003, nr 8, s. 11; K. Zagrobelny, [w:] Kodeks cywilny, t. 2. Komentarz do artykułów 535-1088, red. E. Gniewek, Warszawa 2004, s. 233; J. Strzępka, B. Sagan, E. Zielińska, Zmiany $w$ zakresie uregulowań administracyjnoprawnych $i$ cywilnoprawnych $w$ umowach budowlanych, Warszawa 2003, s. 15-16, przy czym dodatkowo rozważa się, czy brak zgody powoduje nieważność, czy bezskuteczność umowy, z ostatecznym wskazaniem na tę drugą możliwość, co jest o tyle zaskakujące, że na tle art. 63 k.c. najpierw pojawia się bezskuteczność zawieszona przechodząca (w razie braku zgody) w nieważność czynności dokonanej bez wymaganej zgody osoby trzeciej.

17 A. Brzozowski, Solidarna odpowiedzialność inwestora i wykonawcy (generalnego wykonawcy) za zapłate wynagrodzenia należnego podwykonawcom w świetle art. $647^{1}$ k.c., [w:] Odpowiedzialność cywilna. Księga pamiątkowa ku czci Profesora Adama Szpunara, red. M. Pyziak-Szafnicka, Kraków 2004, s. 310. 
$\S 1$ k.c. dotychczasowy model wykonawstwa ${ }^{18}$ pozwalający wykonawcy spełniającemu świadczenie swobodnie korzystać z pomocy podwykonawców, ale równocześnie za nich także odpowiadać (art. 474 k.c.). Miałby go zastąpić model, w którym to inwestor ostatecznie decyduje o możliwości korzystania przez wykonawcę $\mathrm{z}$ określonego podwykonawcy ${ }^{19}$, a godząc się na to — solidarnie z wykonawcą odpowie za zapłatę wynagrodzenia podwykonawcy. Być może w nowelizacji kodeksu cywilnego jednak chodzi wyłącznie o to, aby w ramach poprawy sytuacji podwykonawcy zapewnić mu dodatkowego, solidarnego dłużnika, o ile zgodzi się on ponosić tę odpowiedzialność. Przyjęcie pierwszego modelu, nawet niesygnalizowanego w motywach nowelizacji, musiało prowadzić do skutków przynajmniej częściowo odmiennych od zakładanych, komplikując i tak niełatwy proces budowlany. W ramach doktrynalnej dyskusji nad solidarną odpowiedzialnością inwestora zgłoszono postulat oparcia się na wykładni funkcjonalnej art. $647^{1}$ k.c., odrzucając wykładnię skupioną na dosłownej jego treści z odwołaniem się do art. 63 k.c. ${ }^{20}$ Zasadniczym powodem takiej sugestii było spostrzeżenie, że funkcją przepisu art. $647^{1} \S 2$ k.c. stanowiącego o zgodzie inwestora na zawarcie umowy podwykonawczej wcale nie jest kontrola inwestora nad określonym w umowie zakresem robót wykonywanych przez wykonawcę osobiście i za pomocą podwykonawców, ponieważ i tak można go w każdej chwili modyfikować. Wystarczy do tego zgodna wola inwestora i wykonawcy. Pomijając nawet wspomnianą dezorganizację samego procesu budowlanego przez konieczność uzyskiwania zgody na zawarcie umowy podwykonawczej, należało mieć na względzie, że w przypadku „dalszych” umów podwykonawczych (art. $647^{1} \S 3$ k.c.) zgodę wyrażać musieliby inwestor i wykonawca, a czasem nawet inwestor, wykonawca i dalszy podwykonawca ${ }^{21}$. Nie ma co ukrywać, że osiągnięcie tak podmiotowo rozbudowanej akceptacji dla skuteczności umowy nie jest rozwiązaniem spotykanym w kodeksie cywilnym. Tam, gdzie ustawowo wymagana jest zgoda osoby trzeciej, odnosi się ona konkretnie do wskazanej osoby, nie zaś szerszego ich $\mathrm{kręgu}^{22}$. Nie są to jedyne trudności wynikające z przyjęcia zgody inwestora jako warunku skuteczności umowy podwykonawczej. Dalszymi jej konsekwencjami byłyby niemałe trudności w rozliczeniu samych stron umowy ostatecznie nieważnej, a jednak przez podwykonawcę zrealizowanej. Warto więc wspomnieć, że w art. $647^{1} \S 2$ k.c. przyjęto również możliwość aplikowania o zgodę inwestora stron zawartej już umowy. Podjęte przez podwykonawcę czynności zmierzające

18 Taką prognozę zawarto w opracowaniu J. Strzępka, B. Sagan, E. Zielińska, op. cit., s. 9.

19 Takie głosy też się pojawiały, przyjmując nietrafnie, że art. $647^{1}$ k.c. wprowadził obowiązek osobistego świadczenia wykonawcy robót budowlanych, zob. przykładowo J. Strzępka, [w:] System Prawa Handlowego, t. 5. Prawo umów handlowych, red. S. Włodyka, Warszawa 2011, s. 1099.

20 B. Kostecki, Uwagi na temat wyktadni przepisu art. $647^{1}$ Kodeksu cywilnego, PUG 7, 2004, s. 21.

21 Ibidem.

22 Pomijam tu przypadki zgody małżonków. 
do jej wykonania trzeba by ostatecznie oceniać nie jako spełnienie przez niego świadczenia, ale jako przypadek świadczenia nienależnego prowadzący do uruchomienia szczególnych rozliczeń. Ich podstawą nie byłyby wspólnie ustalone postanowienia umowy, ponieważ ostatecznie okazała się ona nieważna. Rozliczenie nienależnego świadczenia podwykonawcy trzeba by oprzeć na regułach rządzących zwrotem nienależnego świadczenia (art. 405 i nast. k.c.), co — jak można przypuszczać — rzadko kiedy byłoby dla niego rozwiązaniem korzystnym. W wypadku zaś podmiotów profesjonalnych uczestniczących zwłaszcza w budowach o większym rozmiarze konsekwencje podatkowe takiego rozliczenia mogą być trudne do wyobrażenia, zmieniając całkowicie wymiar finansowy przedsięwzięcia ${ }^{23}$. Wydaje się, że zaskakujące i nieoczekiwane konsekwencje mogłyby dotknąć także inwestora odmawiającego akceptacji umowy podwykonawczej. Wiązałoby się to z tym, że rezygnacja $\mathrm{z}$ dotychczasowego modelu wykonywania umowy o roboty budowlane zakładającego swobodę wykonawcy w wyborze podwykonawcy wpływałaby na jego odpowiedzialność za ich działania. Należy pamiętać, że według obowiązującej konstrukcji wykorzystującej art. $356 \S 1$ k.c. i art. 474 k.c. wykonawca, mogąc powierzyć podwykonawcom wykonanie części lub nawet całość świadczenia, ponosi za nich odpowiedzialność. Gdy zachowanie pomocników narusza zobowiązanie łączące go z inwestorem, stanowi to jednocześnie niewykonanie lub nienależyte wykonanie tego zobowiązania. W sytuacji nieistnienia umowy podwykonawczej trudno pozbyć się wątpliwości, czy działanie podwykonawcy da się zarachować na rzecz kontrahenta-inwestora i obciążyć go skutkami takiego działania. Uwzględniając zatem podniesione zastrzeżenia ${ }^{24}$ związane z przyjęciem konstrukcji zgody inwestora jako zgody z art. 63 k.c. decydującej o umowie podwykonawczej, zrezygnowano $\mathrm{z}$ tej koncepcji zgody na rzecz odejścia od dosłownego brzmienia $647^{1} \S 2$ k.c. i wykładania go według dyrektywy funkcjonalnej.

7. Odrzucenie wspomnianej konstrukcji zgody osoby trzeciej spowodowało, że zupełnie inaczej dało się postrzegać nowe rozwiązanie to przede wszystkim właśnie przez pryzmat wartości, jakie temu przedsięwzięciu towarzyszyły i podlegały ochronie. Zyskało ono silne uzasadnienie aksjologiczne w ocenach, które można przypisać prawodawcy, a co — jak wiadomo - jest cechą wykładni funkcjonalnej ${ }^{25}$. W tym ujęciu inwestor i odpowiednio wykonawca, wyrażając zgodą na zawarcie umowy podwykonawczej, w istocie rzeczy decydowali o kwestii najważniejszej — o tym mianowicie, czy roszczenie podwykonawcy o zapłatę wynagrodzenia za wykonane roboty budowlane zyska dodatkowe wzmocnienie w postaci dhugu solidarnego po stronie inwestora. Zgoda inwestora $\mathrm{w}$ żaden sposób nie wpływa na ważność umowy, jaką poszczególni uczestnicy procesu inwe-

${ }^{23}$ Chodzi zwłaszcza o rozliczenie podatku VAT, które - w sytuacji braku umowy będącej podstawą rozliczeń — stawały się niejasne.

24 A są jeszcze inne, których omawianie nie jest konieczne w tym opracowaniu.

25 S. Wronkowska, Podstawowe pojęcia prawa i prawodawstwa, Poznań 2005, s. 85. 
stycyjnego zamierzali zawierać lub już zawarli, chcąc wywiązać się z obowiązku realizacji określonego fragmentu obiektu stanowiącego przedmiot świadczenia wykonawcy robót budowlanych. Trzeba pamiętać, że proces inwestycyjny wręcz zakłada konieczność występowania w nim wielu różnych podmiotów o szczególnych kwalifikacjach, których jeden, nawet duży wykonawca zwykle nie posiada. Krępowanie wykonawcy koniecznością uzyskania zgody inwestora na korzystanie z podwykonawców nie dość, że sprzeczne z zasadami prakseologii, dodatkowo musiałoby burzyć dotychczasowe formy ich zatrudnienia, co w świetle dostępnego uzasadnienia nowelizacji trudno uznać za jej zamierzony cel. Skorzystanie z dyrektyw funkcjonalnych przy thumaczeniu art. $647^{1}$ k.c. sprawiło ponadto, że wyjaśniła się kolejna kontrowersja związana z umowami podwykonawczymi. Pozwoliło ono przyjąć, że jedne z nich, zawarte z aprobatą inwestora, czyniły go dłużnikiem solidarnym odpowiadającym za zapłatę wynagrodzenia podwykonawcy. Można więc ten element treści uznać za ich accidentalia negotii. Inne umowy podwykonawcze, zawarte bez wspomnianej zgody, nie są nieważne, lecz nie rodzą dodatkowych, wspomnianych następstw, ograniczając swoje oddziaływanie do klasycznej relacji inter partes. Pobocznym, chociaż wcale nie nieistotnym skutkiem przyjętego sposobu wykładni art. $647^{1}$ k.c., było również rozstrzygnięcie niejasnej relacji między jego $\S 4$ i art. 648 k.c. Przepisy te dotyczą formy umowy o roboty budowlane. Ich niesprzeczna z sobą wykładnia uwzględniająca ustalenia funkcjonalnej oceny dodanego przepisu pozwoliła przyjąć, że nadal pisemna forma ad probationem pozostaje wiodącym rozwiązaniem obowiązującym strony zawierające umowę o roboty budowlane, a należy pamiętać, że taki charakter mają umowy podwykonawcze ${ }^{26}$. W relacjach między przedsiębiorcami również ten wymóg ulega złagodzeniu (art. $74 \S 4$ k.c.), co sprawia, że można ją zawrzeć w sposób nieformalny i to nawet per facta concludentia. Natomiast podwykonawcza umowa o roboty budowlane wymaga zachowania szczególnej ad solemnitatem formy wyłącznie wtedy, gdy za zgodą inwestora czyniła go dłużnikiem solidarnym podwykonawcy ${ }^{27}$.

Przedstawione rozważania wskazują, że w procesie wykładni przepisów prawa cywilnego koncentrowanie się wyłącznie na dyrektywach językowych i systemowych nie zawsze wystarczy, aby ustalić treść określonego przepisu. Wspomaganie się wykładnią funkcjonalną będącą emanacją założenia o racjonalnym prawodawcy może ułatwić, a czasem — jak w analizowanym przypadku — być wręcz niezbędne do odkodowania treści ocenianej normy. $Z$ prowadzonego wywodu ponadto wynika sugestia, że w ramach paradygmatu o racjonalnym prawodawcy ważniejszą rolę mają przypisywane mu wartości niż poszukiwanie „rzeczywistego” prawodawcy.

26 Nietrafnie T. Szanciło, Solidarna odpowiedzialność inwestora za zapłatę wynagrodzenia za roboty budowlane, KPP 2016, z. 2, s. 436-437, którego zdaniem każda umowa podwykonawcza wymaga zachowania formy pisemnej ad solemnitatem.

27 Niespójność powołanych przepisów dostrzegał między innymi M. Gutowski, [w:] Kodeks cywilny, t. 2. Komentarz, nb 3 do art. 648, red. M. Gutowski, Legalis. 


\title{
REASONABLE EMPLOYER - AID FOR JOINT AND SEVERAL LIABILITY OF AN ENTREPRENEUR FOR PAYING THE REMUNERATION OF A SUBCONTRACTOR
}

\author{
Summary
}

The implementation of joint and several liability of the investor to the Polish Civil Code (CC) was to be a remedy for payment problems of subcontractors that had not received their remuneration for construction works that they had conducted. By agreeing to conclude a subcontracting agreement, the investor was to jointly and severally be liable with the contractor for paying the remuneration of the subcontractor. The manner of drawing up Article $647^{1}$ of the CC did not allow for achieving the goals assumed by the employer, thus it was necessary to refer to the paradigm of a reasonable employer. Only then was that provision able to gain an acceptable and internally consistent content.

Keywords: construction works contract, investor, contractor, subcontractor, joint and several liability of the investor, reasonable employer

\section{BIBLIOGRAFIA}

Borowicz A., Argument interpretacyjny odwolujacy się do woli rzeczywistego prawodawcy „Studia Prawno-Ekonomiczne" 79, 2009.

Brzozowski A., Solidarna odpowiedzialność inwestora i wykonawcy (generalnego wykonawcy) za zapłate wynagrodzenia należnego podwykonawcom w świetle art. $647^{1}$ k.c., [w:] Odpowiedzialność cywilna. Ksiegga pamiatkowa ku czci Profesora Adama Szpunara, red. M. Pyziak-Szafnicka, Kraków 2004.

Drapała P., Umowa o roboty budowlane, PPH 2003.

Gutowski M., [w:] Kodeks cywilny, t. 2. Komentarz nb 3 do art. 648, Legalis.

Kantor-Kozdrowicki P., Racjonalność prawodawcy jako paradygmat nauk prawnych, „Folia Iuridica Universitatis Wratislaviensis" 7, 2018.

Kostecki B., Uwagi na temat wyktadni przepisu art. $647^{1}$ Kodeksu cywilnego, PUG 7, 2004.

Machnikowski P., [w:] Kodeks cywilny. Komentarz, red. E. Gniewek, P. Machnikowski, Warszawa 2019.

Machnikowski P., [w:] Zarys prawa cywilnego, red. E. Gniewek, P. Machnikowski, Warszawa 2018.

Nowak L., Interpretacja prawnicza. Studium z metodologii prawoznawstwa, Warszawa 1973.

Radwański Z., Olejniczak A., Prawo cywilne - część ogólna, Warszawa 2017.

Strzępka J., [w:] System Prawa Handlowego, t. 5. Prawo umów handlowych, red. S. Włodyka, Warszawa 2011.

Strzępka J., Sagan B., Zielińska E., Zmiany w zakresie uregulowań administracyjnoprawnych i cywilnoprawnych w umowach budowlanych, Warszawa 2003.

Szenkowski D., Pluralizm wartości a wola i racjonalność ustawodawcy — konflikt aksjologiczny w systemie i stosowaniu prawa, „Dialogi Polityczne” 2010, nr 13.

Szanciło T., Solidarna odpowiedzialność inwestora za zapłate wynagrodzenia za roboty budowlane, KPP 2016, z. 2.

Wronkowska S., Podstawowe pojęcia prawa i prawodawstwa, Poznań 2005.

Zagrobelny K., [w:] Kodeks cywilny, t. 2. Komentarz do artykułów 535-1088, red. E. Gniewek, Warszawa 2004. 